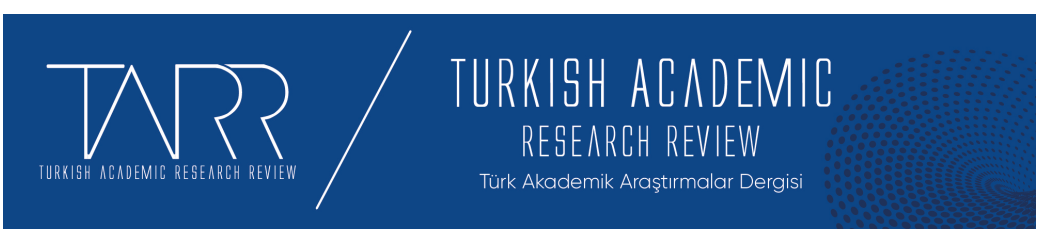

e-ISSN: 2602-2923 Yıl/Year: 2021 Cilt/Volume: 6 Sayı/Issue: 4

\title{
Üniteryanizm ve Teslis Eleştirisi
}

Unitarianism and The Criticism of The Trinity

\section{İbrahim KAPLAN}

Doç. Dr., İzmir Kâtip Çelebi Üniversitesi, İslâmî İlimler Fakültesi, Temel İslam Bilimleri Bölümü / Assoc. Prof. Dr., İzmir Kâtip Çelebi University, Faculty of Islamic Sciences, Department of Basic Islamic Sciences, ibrahim.kaplan@ikc.edu.tr, Orcid ID: 0000-0002-4739-6669

\begin{tabular}{r|l} 
Makale Bilgisi & Article Information \\
Makale Türü - Article Type & Araştırma Makalesi / Research Article \\
Geliş Tarihi - Date Received & 15 Kasım / November 2021 \\
Kabul Tarihi - Date Accepted & 25 Aralık / December 2021 \\
Yayın Tarihi - Date Published & 31 Aralık / December 2021 \\
Yayın Sezonu & Aralık Özel Sayı \\
Pub Date Season & December Special Issue
\end{tabular}

Atıf/Cite as: Kaplan, İ., (2021), Üniteryanizm ve Teslis Eleştirisi/ Unitarianism and The Criticism of The Trinity. Turkish Academic Research Review, 6 (4), 85-107. Retrieved from https://dergipark.org.tr/tr/pub/tarr/issue/67631/1024112

Intihal / Plagiarism: Bu makale, en az iki hakem tarafından incelenmiş ve intihal içermediği teyit edilmiştir. / This article has been reviewed by at least two referees and confirmed to include no plagiarism. https://dergipark.org.tr/tr/pub/tarr

Copyright (C) Published by Mehmet ŞAHİN Since 2016- Akdeniz University, Faculty of Theology, Antalya, 07058 Turkey. All rights reserved.

Turkish Academic Research Review - Türk Akademik Araştırmalar Dergisi 


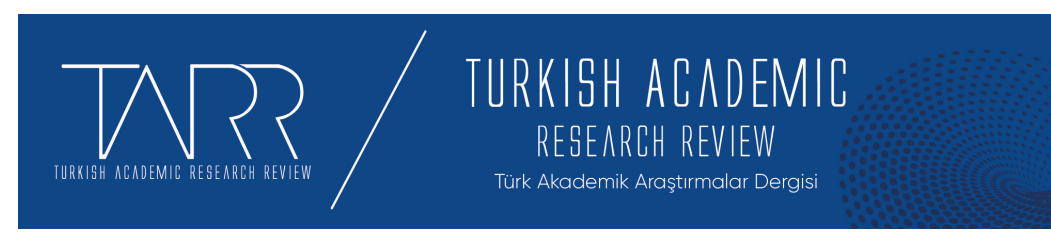

e-ISSN: 2602-2923 Yıl/Year: 2021 Cilt/Volume: 6 Sayı/Issue: 4

\author{
Üniteryanizm ve Teslis Eleştirisi \\ “Bir adamı yakmakla bir doktrin ispat edilemez.” (Kastillo)
}

\author{
İbrahim KAPLAN
}

Öz

Hıristiyan ilahiyatçılar Hıristiyanlığın monoteist karakterli bir din olduğu noktasında ittifak halinde olsalar da inanç esaslarının temelini oluşturan teslis doktrininin monoteizme uygunluğu hususunda ihtilaf etmişlerdir. Özellikle anti-trinitarian olarak nitelendirilen tevhidci Hıristiyanlar, Hz. İsa'nın gerçek öğretisinin tektanrıcılığı esas aldığını, daha sonraki dönemlerde bu öğretinin dejenerasyona uğradığını iddia etmektedirler. Evrendeki ahenk ve düzenin Tanrının birliğine bağlı olduğunu söyleyerek tevhide vurgu yapan Üniteryanlar, dinî ve ahlâkî bir lider olarak kabul ettikleri İsa Mesih'in tanrılaştırılmasına karşı çıkarlar. Üniteryanlara göre, Eski Ahit'te de Yeni Ahit'te de Tanrı'nın mutlak anlamda bir olduğu vurgulanmaktadır. Dolayısıyla teslis öğretisinin kaynağı Hıristiyan kutsal metinleri değildir. Onlara göre, insanların kendilerini, içindeki yaşadıkları evreni ve Tanrılarını anlama konusunda uzun bir mücadelenin kaydı olarak gördükleri İncil, insan yazarlar tarafindan kaleme alınmış en iyi rehberdir. Ancak İncil, tartışılmaz bir otorite değildir. Bu yüzden içeriği akıl ve vicdan ıșığında yorumlanmalıdır. Zira İsa'nın kendisi de Kutsal Kitap'ın yanılmazlığından bahsetmemiştir.

$\mathrm{Bu}$ makale teslis karşıtı görüşleriyle bilinen teolojik bir akım olan Üniteryanizm'in teslis eleştirisini konu edinmektedir. Bizzat Hıristiyan dinî atmosferi içinde doğup gelişen, ancak Hıristiyan iman esaslarının temelini oluşturan teslis doktrinine muhalif fikirleriyle öne çıkan bu teolojik akımın teslisin tutarsızlıklarını ortaya koyan görüşleriyle tanıtılması hem Dinler Tarihi hem de Kelam araştırmaları açısından önemlidir. Üniteryanizm'in doğuşu ve gelişim süreçlerini ele alan akademik çalışmalar, az da olsa mevcuttur. Ancak teslise yönelik eleştirileriyle Üniteryanizm ele alınmış değildir. Dolayısıyla bu çalışmada teslise yönelik eleştirileri bağlamında Üniteryanizm ele alınmıştır. Üniteryanizm'in teslis eleştirisinde dikkat çeken ilk husus teslis doktrinin kaynağının Hıristiyan kutsal metinleri olmadığı yönündeki tespitleridir. İkinci olarak Üniteryanlar, teslis doktrininin akıl ve mantık ilkeleriyle de bağdaşmadığını iddia etmişler ve bu görüşlerini çeşitli yöntemlerle ispatlamaya gayret etmişlerdir. Özelde Üniteryanların genelde de tevhidci Hıristiyanların teslis eleştirilerinin İsa'nın saf ve katışıksız öğretilerini yeniden hâkim kılma gayesiyle şekillendiği söylenebilir.

Anahtar Kelimeler: Üniteryanizm, Anti-Trinitaryanlar, Huristiyanlık, Teslis, Tektanrıcılık, Tevhid.

\title{
Unitarianism and The Criticism of The Trinity
}

\section{Abstract}

Although Christian theologians are unanimous on the point that Christianity is a religion with a monotheistic character, they have disagreed on the compatibility of the doctrine of the Trinity, which forms the basis of the principles of belief, with

Turkish Academic Research Review - Türk Akademik Araştırmalar Dergisi 
monotheism. In particular, monotheistic Christians, who are described as antitrinitarian, claim that the true teaching of the Prophet Jesus was based on monotheism, and this teaching degenerated in later periods. Unitarians, who emphasize tawheed by saying that the harmony and order in the universe depend on the unity of God, oppose the deification of Jesus Christ, whom they accept as a religious and moral leader. According to the Unitarians, it is emphasized that God is one in the absolute sense in both the Old Testament and the New Testament. Therefore, the source of the doctrine of the trinity is not the Christian scriptures. According to them, the Bible is the best guide written by human writers which people see as the record of a long struggle to understand themselves, the universe in which they live, and their God. But the Bible is not an indisputable authority. Therefore, its content should be interpreted with reason and conscience, because Jesus himself did not mention the infallibility of the Bible.

This article deals with the trinity critique of Unitarianism, a theological movement known for its anti-trinitarian views. Both History of Religions and Kalam studies needs to introduce this theological movement, which was born and developed in the Christian religious atmosphere but stands out with its ideas that are opposed to the doctrine of the trinity, which forms the basis of the Christian faith, and this movement's views revealing the inconsistencies of the trinity. There are, albeit few, academic studies dealing with the birth and development processes of Unitarianism. However, Unitarianism has not been addressed with its criticisms of the Trinity. Therefore, in this study, Unitarianism is discussed in the context of its criticism of the trinity. The first point that draws attention to the trinity criticism of Unitarianism is the determination that the source of the trinity doctrine is not the Christian scriptures. Secondly, Unitarians claimed that the doctrine of the Trinity was incompatible with the principles of reason and logic, and they tried to prove their views with various methods. We can say that the trinity criticisms of the Unitarians in particular and the monotheistic Christians in general were shaped to remake the pure and absolute teachings of Jesus.

Keywords: Unitarianism, Anti-Trinitarians, Christianity, Trinity, Monoteism, Tawheed.

\section{Structured Abstract}

The first sources of Christianity show that the first Christians, especially the apostles, adopted the principle of tawheed and accepted Jesus as a human and a messenger of God. When the conflicts that led to the convening of the councils are reviewed, it will be seen that the creed of tawheed has been adopted and defended by many thinkers and schools in Christian thought from its earliest times. While the first Christians tried to establish monotheism, this idea later shifted to a triple god understanding. Today, the studies on the New Testament and the origin of Christianity in Europe also support the claims that Christianity started with the belief in one God, then deteriorated and turned into the trinity doctrine.

Unitarianism, which stands out with its opposition to the doctrine of the Trinity, seems to have failed to attract the attention of those who research the field of theology. However, Unitarians, who insistently emphasize the unity of God and the human being of Jesus, claim that the teachings of Jesus Christ were altered by the Christians themselves, thus, Christianity lost its monotheistic character and became a belief system formed by councils. This claim of theirs is compatible with what the Qur'an and the refutations against Christianity say on this subject. We aim to introduce Unitarianism, which emerged in the 16th century, but whose origins date back to the first centuries of Christianity, and which still finds supporters and operates in many parts of the Christian world, with its criticisms of the trinity. 
Michael Servetus (1511-1553) is accepted as the pioneer of Unitarianism, a theological movement distinguished by its opposing views on the doctrine of the Trinity. Servetus emphasizes tawheed by saying that the orderly functioning in the world depends on the unity of God, and opposes the deification of Jesus Christ, a religious and moral leader, by removing him from the position of a prophet. One of the awe that Servetus opposes is the doctrine of incarnation that Jesus paid for sin with his life to quell God's anger. According to Servetus, this claim is an ugly slander against the merciful God. These summarized views caused Servetus to be described as a "Muslim" and to be burned alive with his works.

Unitarianism, which emerged in Poland and Transylvania in the second half of the 16th century and established an organized church, found supporters in England and America shortly after its establishment. Today, Unitarians, operating in various parts of the world, reject many traditional doctrines of Christianity, especially the Trinity, and defend the unity of God. Unitarians, who insist that God is one in the absolute sense and that Jesus is a human being, are not bound by any credo. Unitarians rely on the determination of the human mind instead of the authorities in matters related to faith. While respecting the memory of Jesus and accepting the greatness of his knowledge, Unitarians who admit that he is not infallible do not accept the miraculous birth of Jesus. According to them, Jesus is a human being born of the carpenter Joseph of Nazareth and Mary. Nor do they admit the "original sin" doctrine that man is a born sinner. According to them, there is no sin inherited from the Prophet Adam and Eve. Everyone is responsible for their actions and no one takes the blame for anyone else. The Unitarians, who oppose the original sin doctrine of Christianity, used the baptismal sacrament, which has been practiced in the Christian world for centuries and made to purify it from original sin, as "a sincere expression of gratitude for the blessing of the child bestowed by God, and the promise that this given child will be brought up by God's will," they consider and implement. The Evharistiya sacrament, which is understood as sharing the body and blood of Jesus Christ with bread and wine, has been transformed by Unitarians into "a ritual that reminds Jesus' message, revives his suffering for the truth, and thereby improves people religiously and morally."

The Unitarian movement, which has acted on the same plane with the religious movements that have discussed the doctrine of the trinity since the first periods of Christianity, aimed to reveal the true teachings of the Bible and the pure state of Christianity before the degeneration. Unitarians, who first applied to the Christian scriptures for this purpose, determined that the trinity did not originate from the Old and New Testaments and that there was a strong emphasis on the unity of God in these texts. In other words, the trinity is not teaching originating from Christian scriptures. Moreover, Jesus never said that he was an element of God. This issue is similarly expressed in the Qur'an, it is reminded that Jesus would never say such a thing and that Jesus said to them, "Worship Allah, my Lord and your Lord," (Maide, 116-117). Based on this and many other similar expressions, it is possible to talk about the influence of the Qur'an in the trinity criticism of the Unitarians. On the other hand, according to them, the belief in the trinity, which divides an ore into three separate elements (uknuma), thus reaching a triple god understanding and moving away from the principle of the unity of God, is also incompatible with the principles of reason and logic. As such, trinity dogma is a belief system that not only Muslims and Jews, but even wild animals see as absurd and logically inconsistent. According to the Unitarians, although traditional Christianity did not say, "God is three," it reached the conception of a triple god or a god with three appearances, yet it contradicted itself by saying that it was monotheistic. According to the Unitarians, the trinity, consisting of the Father, the Son and the Holy Spirit, and which envisages three beings in one nature, is a doctrine that has been scammed under the name of tawheed and is problematic in terms of its reasonableness and logicality. In addition, the acceptance in this teaching that Jesus had both a human and a divine nature is a belief that is

Turkish Academic Research Review - Türk Akademik Araştırmalar Dergisi 
difficult or even impossible to explain rationally. Because this belief is contradictory because two different characters cannot exist simultaneously in a being.

\section{Giriş}

Geçmişten bugüne Hıristiyan düşüncede Hz. İsa'nın tabiatıyla ilgili farklı yorum ve tartışmalar olsa da, Hıristiyan ilahiyatçıların tamamı Hıristiyanlığın monoteist karakterli bir din olduğu konusunda uzlaşı halindedirler. Ancak, Hıristiyanların inanç esaslarının temelini oluşturan teslis doktrininin monoteizme uygun olup olmadığı hususunda aynı uzlaşıdan söz etmek mümkün görünmemektedir. ${ }^{1}$ Teslisi savunan ve kendini "trinitarian" olarak isimlendiren Hıristiyan ilahiyatçılar, bu doktrinin aslında üçlü Tanrı anlayışını (tritheizm) değil üçlü-birliği ifade ettiği, dolayısıyla tektanrıcı yani monoteist karakterli bir inanç sistemi olduğu konusunda 1srarcıdır. ${ }^{2}$ Buna karşın Tanrı’nın birliğini ısrarla vurgulayan "Anti-trinitarian" ya da "Unitarian" olarak isimlendirilen Hiristiyan ilahiyatçılar, teslisin monoteizme aykırı olduğunu, dolayısıyla da inanç esası sayılamayacağını iddia etmektedirler. Onlara göre, bir tabiatta üç ayrı şahsın bulunması aklın kabul edebileceği bir şey değildir. Diğer taraftan Hıristiyan Kutsal Metinleri de Tanrı'nın mutlak anlamda bir olduğunu ısrarla vurgulamaktadır. Dolayısıyla Tanrı'nın üçlü-birliğini ifade eden teslis hem akla hem de Kutsal Metinlere uygun bir doktrin değildir. ${ }^{3}$

Hıristiyanlığa ait ilk kaynaklara göre başta havariler olmak üzere, ilk Hıristiyanların ve ilk Hıristiyan cemaatlerin tevhid ilkesini benimsedikleri, Hz. İsa’yı

\footnotetext{
${ }^{1}$ Hıristiyanlığın erken dönemlerinde Ignatius (ö. 107), Iustinus (ö. 165), Irenaeus (ö. 202), Tertullianus (ö. 240), Origenes (ö. 254) gibi Kilise yazarlarının eserlerinde İsa'yı bir beşer olarak kabul edenlerin görüşleri nakledilmektedir. (Zafer Duygu, İsa, Pavlus ve Inciller, Düşün Yay., İstanbul, 2021, 632 vd.)

${ }^{2}$ C. Stephen Layman, "Tritheism and the Trinity", Faith and Pholosophy, vol. 5, No. 3, July 1988, 291- 298; Carlos Madrigel, Hiristiyanların Üçlü-Birlik (Tevhit'de Teslis) Ínancı Ne Demek?, Müjde Yayıncılık, İstanbul, 1995, 14-19, 49-58; Karl Rahner, "Trinity, Divine", Encyclopedia of Theology, ed., Karl Rahner, Crossroad, New York, 1986, 1755-1771;Catherine M. Lacguna, “Trinity”, The Encyclopedia of Religion, ed. Mircea Eliade, Macmillan Publishing Company, New York, 1987, C. XV, 53-57; John Macnamara-Marie La Palme Reyes-Gonzalo E. Reyes, "Logic and the Trinity", Faith and Pholosophy, vol. 11, no. 1, January 1994, 3-18; Richard Swinburne, "Trinity; A Defense of the Doctrine of the Trinity", Philosophy of Religion, ed., Lane Crcig, Rutgers University Pres, New Jersey, 2002, 556-567; Thomas Michel, Hiristiyan Tanribilimine Giriş, Ohan Yay., İstanbul, 1992, 64-65; Christian W. Trol, Müslümanlar Soruyor Hıristiyanlar Yanitlyyor, çev., Robert Kaya, İstanbul, t.y., 5051.

3 J. C. Godbey, "Unitarian Universalist Assocation", The Encyclopedia of Religion, ed. Mircea Eliade, Macmillan Publishing Company, New York, 1987, C. XV, 143146.
} 
bir insan ve Tanrı'nın mesajını insanlara iletmekle görevli bir elçi olarak gördükleri anlaşılmaktadır. ${ }^{4}$ Konsillerin toplanmasına sebep olan ihtilaflar gözden geçirildiğinde de ilk devirlerinden itibaren Hiristiyan düşünce içerisinde tevhid akidesinin pek çok düşünür ve ekol tarafından benimsendiği ve savunulduğu görülecektir. ${ }^{5}$ Havarilerin temsilcisi durumundaki Kilise Babaları ve iman esaslarını muhafaza etme amacında olan Apologistler, ${ }^{6}$ bir baba ve kâdir-i mutlak bir tanrı inancını yerleştirmeye çalışırken, bu düşünce daha sonra üçlü bir tanrı anlayışına doğru kaymıştır. ${ }^{7}$ Bugün Batı'da yapılan Yeni Ahit ve Hıristiyanlığın kökenine dair çalışmalar da Hıristiyanlığın tek tanrı inancı ile başlayıp, daha sonra bozulmalara uğrayarak teslis doktrinine dönüştüğü yönündeki iddiaları destekleyecek mahiyettedir. ${ }^{8}$ Weigall'in deyimiyle; "İsa tarafından dışarı atılan eski tanrılar tekrar nüfuz ettiler ve bir kez daha kendilerini meydana çıkardılar. Onların tapınakları yok edildi ve sunakları terk edildi. Buna karşılık onlar kiliseye geldiler ve bugün siz onlara, onları kendi şekilleriyle inkâr edenler tarafından başka adlar altında tapıldığını görürsünüz." ${ }^{\prime 9}$ Kısacası Hıristiyanlık tarihi üzerine çalışma yapan güvenilir bir bilim insanının, günümüz Hıristiyanlığının İsa'nın yüzünü örten bir maske olduğunu kabul etmesi için yeterli kanıt vardır. İslâm'ın gelişinden önce de, bugün de Hıristiyan düşünce içerisinde tarihsel İsa'y1 kabul edip maskeyi reddedenler olmuştur. ${ }^{10}$

Teslis doktrinine muhalif fikirleriyle öne çıkan Üniteryanizm, ilahiyat alanında araştırma yapanların dikkatini yeterince çekememiş görünmektedir. Hâlbuki Tanrı'nın birliğini ve İsa'nın insan oluşunu israrla vurgulayan Üniteryanlar, Hz. İsa'nın öğretilerinin bizzat Hıristiyanlar tarafından başkalaştırıldığını, böylece Hıristiyanlığın tektanrıcı karakterini yitirerek, anlamsız kavramlarla örülen bir inanç sistemi haline getirildiğini iddia etmektedir. Üniteryanların bu iddialarını hangi usul

\footnotetext{
4 Joseph Hanry Allen, "Early Christian Doctrin", Unitarianism: Its Origin and History, American Unitarian Assocation, Boston, 1890, 1-2; Mehmet Bayrakdar, Bir Hıristiyan Dogması Teslis, Ankara Okulu Yay., Ankara, 2007, 17.

${ }^{5}$ Muhammed Ebu Zehre, Hiristiyanlık Üzerine Konferanslar, çev., Akif Nuri, Fikir Yay, İstanbul, 1978, 256.

${ }^{6}$ II. Yüzyıl ile IV. yüzyıl arasında, Hıristiyan imanını sapkın saydıkları gnostisizm ve ateizm gibi öğretilere karşı savunmak amacıyla kalem oynatan aralarında Aziz İustinos, Tatianos, Apollinarios, Meliton, Kodratos, Aristeides gibi isimleri sayılan teologlar topluluğu; Hıristiyanlığa yapılan saldırılara cevaplar yazan Kilise Babaları. Ahmet Cevizci, Felsefe Sözlüğ̈̈, Paradigma Yay., İstanbul, 2002, 80; Mehmet Çelik, Süryani Tarihi, Ayraç Yay., Ankara, 1996, I, 79.

${ }^{7}$ Ali İsra Güngör, Vatikan, Misyon ve Diyalog, Alperen Yay., Ankara, 2002, 31-32.

${ }^{8}$ Geniş bilgi için bkz., Muhammed el-Behiy, İslâm Düşüncesinin İlâhî Yönü, çev., Sabri Hizmetli, Fecr Yay., Ankara, 1992, 85-86.

${ }^{9}$ Arthur Weigall, Hiristiyanlığımızdaki Putperestlik, Ozan Yay., İstanbul, 2002, 13.

${ }^{10}$ Muhammed Ataurrahîm, Bir İslâm Peygamberi Hz. İsa, çev., Kürşat Demirci, İnsan Yay., İstanbul, 1997, 7.
}

Turkish Academic Research Review - Türk Akademik Araştırmalar Dergisi 
ve esaslara göre temellendirdikleri, iddialarını ispatlamak için Hıristiyan kutsal metinlerinden referanslarının neler olduğu araştırmanın ana problematiğini oluşturmaktadır.

Üniteryanizm hakkında yapılacak bir literatür taraması ülkemizde biri doktora diğeri de yüksek lisans olmak üzere iki akademik çalışma yapıldığını göstermektedir. Üniteryanizm'in temel kaynaklarına müracaatla hazırlanan İsmail Yılmaz'n Üniteryanizm'in Doğuşu ve Bunu Etkileyen Dinî Faktörler adlı doktora tezi, konu başlığından da anlaşılacağı üzere, Üniteryanizm'in ortaya çıkış sürecini ve bunu etkileyen dinî faktörleri ele alan ve Dinler Tarihi metodolojisiyle yapılmış bir araştırmadır. Yine sözü edilen tez, bu konuda Türkçe yazılmış ilk eser olma özelliğini taşımaktadır. Kübra Tekin'in Erken Orta Çağ'daki Arianizm Tartışmaları ve Günümüz Üniteryanizm'e Etkileril ${ }^{l 1}$ başlıklı Yüksek Lisans tezi de Arianizm'in Üniteryanizm'e etkisini araştırma konusu edinmiştir. Sözü edilen bu çalışmalar alana önemli katkılar sağlasa da teslise yönelik eleştirileri özelinde bir çalışmaya ihtiyaç olduğunu düşünmekteyiz. Bu anlamda, Üniteryanizm ve Teslis Eleştirisi konulu makalemiz literatürdeki bu boşluğu bir nebze de olsa doldurmayı amaçlaması açısından önemlidir.

Hıristiyan dinî atmosferi içerisinden neşet eden söz konusu teolojik akım, teslis doktrinini değerlendirme konusunda bizi bazı önyargılarımızdan koruyabilme ve bir dini kendi bünyesinden çıkan bir akımın farklı bakış açısıyla tanıtma potansiyeli barındırmaktadır. ${ }^{12} \mathrm{Bu}$ yönüyle Dinler Tarihi araştırmalarında yeni çalışma sahalarına dikkat çekmesi bakımından önemli olan konu, diğer taraftan Kelam araştırmaları ve karşılaştırmalı dinler teolojisi açısından da önemlidir. Keza ele alınan konu Kur'an'daki Ehl-i Kitap ve Hıristiyanlardan bahseden ayetlerin doğru anlaşılmasına katkı sağlamayı amaçlaması açısından da ayrı bir öneme haizdir.

XVI. yy'da ortaya çıkan ancak kökenleri Hıristiyanlığın ilk yüzyıllarına kadar uzanan, bugün de Hıristiyan dünyanın pek çok yerinde taraftar bulan ve faaliyet gösteren Üniteryanizm'in teslise yönelik eleştirileriyle tanıtılması amaçlanmaktadır. Ancak ortaya çıkışından bugüne Üniteryan anlayışta bazı farklılıklar meydana gelmiştir. Bu bakımdan bütün yönleriyle Üniteryanizm müstakil ve kapsamlı bir

11 Kübra Tekin, Erken Orta Çağ'daki Arianizm Tartı̧malarl ve Günümüz Üniteryanizm'e Etkileri, (Tokat Gazi Osman Paşa Üniversitesi Sosyal Bilimler Enstitüsü, Yayımlanmamış Yüksek Lisans Tezi), Tokat, 2019.

12 İsmail Yılmaz, Üniteryanizmim'in Doğuşu ve Bunu Etkileyen Dinî Faktörler, Uludağ Üniversitesi Sosyal Bilimler Enstitüsü yayımlanmamış Doktora Tezi, Bursa, $1994,5$. 
çalışmayı gerektirmektedir. Bu çalışmada Üniteryanizm'i bütün yönleriyle ele alma imkânımız söz konusu değildir. Onun için bu çalışma Üniteryanizm'in ana hatlarıyla tanıtılması ve sözü edilen teolojik akımın teslis eleştirisi ile sınırlı kalacaktır. Üniteryanizm'in ortaya çıkışı ve gelişimini ele almadan önce literatür hakkında kısa bir bilgilendirme, çeşitli yönleriyle bu konuda çalışma yapacak olanlar için fayda sağlayacaktır.

Üniteryanizm hakkında en önemli eser, teslis doktrinine yönelik eleştirileri dolayısıyla Müslüman olmakla suçlanan, Engizisyon tarafindan verilen ceza sonucu eserleriyle birlikte yakılan ve Üniteryanizm'in öncüsü kabul edilen Michael Servetus'un De Trinitatis Erroribus, Libri Septem adl1 eseridir. Servetus'un teslisin hatalarını ortaya koymak için Latince olarak kaleme aldığı bu eseri 1531 yılında yayınlanmış, ${ }^{13}$ Earl Morse Wilbur tarafından On the Errors of the Trinity, Seven Books başlı̆̆ı ile İngilizce'ye tercüme edilmiştir. ${ }^{14} \mathrm{Bu}$ alanda otorite kabul edilen ${ }^{15}$ Wilbur'un A History of Unitarianism adlı eseri de Üniteryanizm hakkında temel başvuru kitaplarından biridir. Eser A History of Unitarianism -Socinianism and its Antecedents ${ }^{16}$ ve $A$ History of Unitarianism -In Transylvania England and America ${ }^{17}$ başlıklarından oluşan iki seri halinde yayınlanmıştır. Wilbur'un Our Unitarian Heritage $^{18}$ adlı çalışması da Üniteryanizm hakkında önemli bir başvuru kaynağıdır. İçerdiği bilgilerle Wilbur'un yukarıdaki bahsettiğimiz serisine ilham kaynağı olan ${ }^{19}$ Joseph Henry Allen'in Historical Sketch of the Unitarian Movement Since the Reformation ${ }^{20}$ adlı çalışması da Üniteryanizm hakkında önemli bilgiler sunmaktadır.

Bunlara ilave olarak, Üniteryanizm hakkında çalışma yapanların müracaat edebileceği temel kaynaklar arasında William George Tarrant'ın Unitarianism,2l

\footnotetext{
${ }^{13}$ Arthur Wilson Fox, Michael Servetus, The Unitarian Library, London, ty., London, 5.

${ }^{14}$ Michael Serveto, On The Errors of The Trinity, Libri Septem, Tr., by Earl Morse Willbur, Harward Theological Studies, XVI, Harwarad University Press, Cambridge, 1932. Yılmaz, Üniteryanizmim'in Doğuşu ve Bunu Etkileyen Dinî Faktörler, 3.

${ }^{15}$ Yılmaz, Üniteryanizmim 'in Doğuşu ve Bunu Etkileyen Dinî Faktörler, 3.

${ }^{16}$ Earl Morse Willbur, A History of Unitarianism-Socinianism and its Antecedents, Harwarad University Press, Cambridge, 1945.

${ }^{17}$ Earl Morse Willbur, A History of Unitarianism -In Transylvania, England and America, Harwarad University Press, Cambridge, 1952.

${ }^{18}$ Earl Morse Willbur, Our Unitarian Heritage, Beacon Press, Boston, 1925.

${ }^{19}$ Yılmaz, Üniteryanizmim 'in Doğuşu ve Bunu Etkileyen Dinî Faktörler, 4.

20 Joseph Hanry Allen, Historical Sketch of the Unitarian Movement Since the Reformation, The American Church History Series, X, The Chiristian Literature Co., New York, 1894.

${ }^{21}$ William George Tarrant, Unitarianism, London, 1912.
}

Turkish Academic Research Review - Türk Akademik Araştırmalar Dergisi 
Ephraim Emerton'un Unitarian Thought ${ }^{22}$; Alfred Hall'ın The Beleifs of A Unitarian ${ }^{23}$ adlı eserleri sayılabilir. Yine Üniteyanizm'in doğuşu ve gelişim süreçleri hakkında bilgi edinmek isteyenler için John White Chadwick'e ait Old and New Belief24 ve American Unitarian Association tarafindan hazırlanan Unitarianism, Its Origin and History ${ }^{25}$ adlı kitaplar müracaat edilmesi gereken eserler arasındadır. Ataurrahim'in, Bir İslâm Peygamberi Hz. İsa adlı çalışması da burada mutlaka zikredilmesi gereken bir kaynak konumundadır.

\section{Anahatlarıyla Üniteryanizm}

En özlü anlatımıyla, üç ayrı uknumdan oluşan tanrı fikrini reddederek Tanrı'nın mutlak anlamda birliğini esas alan, dolayısıyla teslis aleyhtarı bir nitelik taşıyan teolojik bir akım ${ }^{26}$ şeklinde tanımlanan Üniteryanizm, Hz. İsa'nın gerçek öğretisini ortaya çıkarma iddiasıyla rol üstlenmiştir diyebiliriz. Teslis doktrini hakkındaki karşıt görüşleriyle temayüz etmiş teolojik bir akım olan Üniteryanizm'in öncüsü olarak Michael Servetus (1511-1553) kabul edilir. ${ }^{27}$ Servetus, âlemdeki düzenli işleyişin Tanrı'nın birliğine bağlı olduğunu söyleyerek tevhide vurgu yapmakta, dinî ve ahlâkî bir lider olan İsa Mesih'in ilahlaştırılmasına karşı çıkmaktadır. Servetus'un karşı çıktığı hususlardan biri de, Tanrı'nın öfkesini dindirmek için İsa'nın, günahın bedelini canıyla ödediği şeklindeki enkarnasyon öğretisidir. Servetus, söz konusu iddiayı merhamet sahibi Tanrıya karşı yapılmış çirkin bir iftira olarak görmektedir. Özetlenen bu görüşleri Servetus'un "Müslüman" olarak nitelendirilmesine ve eserleriyle birlikte diri diri yakılarak öldürülmesine sebep olmuştur. ${ }^{28}$

Esasında Hıristiyan dünyada yukarıda kısaca özetlenen bu görüşler ilk defa Servetus tarafindan dile getirilmiş değildir. Daha önce de ifade ettiğimiz gibi üniteryan eğilimler, başka bir deyişle Tanrı'nın teslis doktrininde ifade edildiği gibi üç form değil tek bir varlık olduğuna dair tevhidi esas alan yaklaşım Hıristiyanlık tarihinin ilk yüzyıllarına kadar geri gitmektedir. Ancak teolojik üniteryan eğilimlerin

${ }^{22}$ Ephraim Emerton, Unitarian Thought, The Macmillan Company, New Yrok, 1916.

23 Alfred Hall, The Beleifs of A Unitarian, London, 1947.

24 John White Chadwick, Old and New Belief, Boston, 1894.

${ }^{25}$ Yılmaz, Üniteryanizmim 'in Doğuşu ve Bunu Etkileyen Dinî Faktörler, 4

${ }^{26}$ Seth C. Beach, "Unitarianism and The Reformation", Unitarianism: Its Origin and History, Americam Unitarian Assocation. Boston, 1889, 48; J. A. C. Fagginger Auer, "Unitarianism", The Encyclopedia Americana, XXVII, New York-ChiciagoWashington, 1957.

${ }^{27}$ Servetus'un hayatı ve etkileri hakkında geniş bilgi için bkz., Fox, Michael Servetus, $2 \mathrm{vd}$.

${ }^{28}$ Wilbur, Our Unitarian Heritage, I, 59; Tarrant, UNitarianism, 2. 
sistemli bir yapı oluşturması anlamında Üniteryanizm'in başlangıcının Protestan Reformasyonunun gerçekleştiği döneme rastladığını söylemek mümkündür. ${ }^{29}$ Anlaşılan o ki özellikle XV. yy'da İstanbul'un fethi, matbaanın icadı ve coğrafî keşifler gibi bütün dünyayı etkileyen olaylar dinî düşünce alanında da önemli değişikliklerin yaşanmasına sebep olmuş, XVI. yy'da ise bütün bunların yansımaları somut olarak görülmeye başlamıştı. Wilbur'a göre, İstanbul'un Türklerin eline geçmesiyle orada yaşayan Hıristiyan din bilginleri Batı'da karanlık çağlar boyunca unutulmuş olan klasik eserleri de yanlarına alarak Batı Avrupa'ya özellikle de İtalya'ya yerleşmişlerdi. Bu din bilginlerinin yanlarında getirdikleri klasik döneme ait eserlerle oluşturulan kütüphane bilim, sanat ve edebiyat alanında önemli gelişmelere öncülük etmiş, nihayetinde Rönesans ve Hümanizm olarak adlandırılan akımların ortaya çıkışını hazırlamıştı. Yine matbaanın icadı eşine az rastlanır şekilde yeni fikirlerin hızla yayılmasını sağlamıştı. Bundan böyle herkes Kutsal kitaba kolayca ulaşarak onu kendi dilinde okuyabiliyordu. Bunlara ilave olarak coğrafî keşiflerle insanların ufku da oldukça genişlemişti. Bütün bu etkilerle insanlar artık ne sınırlı bir dünyada yaşıyor ne de öncekilerin düşündüklerini düşünmek zorunda kalıyordu. ${ }^{30}$

Sözü edilen gelişmelere bağlı olarak Batı'da dinî düşünce alanında aklın rolünün gittikçe arttığı görülmektedir. Aynı dönemde başlayan reform hareketleri ise bin yılı aşkın süredir Hıristiyan kitle tarafından kabul gören dogmalara karşı eleştirel düşünceyi ve muhalefet hareketini başlatmıştı. ${ }^{31}$

$\mathrm{Bu}$ dönemde teslis dogmasına kaşı eleştiriler yönelten düşünürlerden biri olan ve Üniteryanizm'in öncüsü kabul edilen Michael Servetus 1511 yılında Navarra'ya bağlı Tudela Kasabası'nda dünyaya gelmiş, daha sonra ailesiyle birlikte Villanueva'ya yerleşmiştir. Onun hayatından bahseden kaynaklar, Engizisyon Mahkemelerinin Ortaçağ Hıristiyan ruhunun temsilcisi olan Katolik zihniyete bağlı kalmayanlara ve yaratıcı zekâ sahiplerine, bunun yanı sıra Endülüs'teki Müslümanlara ve Yahudilere uyguladıkları zulümlerin çocukluk yıllarından itibaren onda derin tesirler bıraktığını kaydetmektedir. Bizzat kilise liderleri tarafından sahneye konulan vahşetlerle 1492 'de İspanya'da Hıristiyan olmayı reddeden yüzbinlerce Yahudi sürgün edilirken binlerce Müslüman da yakılarak öldürülmüştü. Bütün bu baskı ve işkencelere rağmen Yahudi ve Müslümanların neden ebedî kurtuluş

29 Wilbur, Our Unitarian Heritage, I, 59; Tarrant, Unitarianism,7; Beach, "Unitarianism and The Reformation", 65; Yılmaz, Üniteryanizmim'in Doğuşu ve Bunu Etkileyen Dinî Faktörler, 53.

${ }^{30}$ Wilbur, Our Unitarian Heritage, 37-38.

${ }^{31}$ Yılmaz, Üniteryanizmim'in Doğuşu ve Bunu Etkileyen Dinî Faktörler, 56.

Turkish Academic Research Review - Türk Akademik Araştırmalar Dergisi https://dergipark.org.tr/tr/pub/tarr 
vadeden Hıristiyanlığı tercih etmediği sorusu Servetus'u teslis doktrini hakkında düşünmeye ve derin araştırmalara sevk etmiştir. ${ }^{32}$ Yine onun teslis doktrinine yönelik sorgulamalarında Kur'an'daki teslis eleştirilerinin etkili olduğunu söylemek mümkündür. ${ }^{33}$ Zira Servetus'un gençliğinin ilk yıllarında Fas'a Arapça öğrenmek için gittiğine dair rivayetler vardır. Bu bilgi kesin olmamakla birlikte onun ilk eserlerinde pek çok Kur'an ayetine işarette bulunduğu belirtilmektedir. ${ }^{34}$ Y 1 lmaz'ın da belirttiği gibi "bu iddia şahit olduğu Engizisyon zulümlerine karşı gelişen nefretiyle birleşince onun niçin teslise tepki duyduğu anlaşılabilir."

Çeşitli sebeplere bağlı olarak gelişen teslis sorgulaması Servetus'u doğal olarak Kutsal Kitap’ı okumaya yönlendirmiştir. Kutsal Kitap’ı doğru anlayabilmek için Grekçe ve İbranice öğrenen Servetus, dikkatli araştırmaları neticesinde teslis doktrininin Kutsal Kitap'a dayanmadığını tespit etmiştir. ${ }^{35}$

Servetus'un geleneksel teslis doktrinine yönelik eleştirileri, Hıristiyan toplum üzerinde, özellikle de Polonya ve Transilvanya'da, büyük etkiler bırakmış ve bu akidenin temellerini sorgulamaya yöneltmiş, bu sorgulamalar neticesinde mahiyet itibariyle Üniteryanizm'in bir türü olan Sozinici akımın (Socinianism) ortaya çıkmasına sebep olmuştur. Socinianism'in öncüsü Faustus Socinus (1539-1604) bu harekete damgasını vuran önemli bir düşünür olarak Üniteryanizm tarihindeki yerini almış ve Polonya'da bu akımın yayılmasında etkili olmuştur. ${ }^{36}$ Üniteyranizm'in Transilvanya-Macaristan'da yayılmasında Francis David (1510-1579) ${ }^{37}$ öne çıkan isim olurken; John Biddle 1615-1662) ve Joseph Priestly (1733-1804)'nin çalışmalarıyla Üniteryanizm İngiltere'de önemli bir ivme kazanmış; James Martineau (1805-1900) harekete yeni bir yorum kazandırmış ve İsa'nın bütünüyle insan

\footnotetext{
${ }^{32}$ Y1lmaz, Üniteryanizmim 'in Doğuşu ve Bunu Etkileyen Dinî Faktörler, 56.

${ }^{33}$ Servetus'un teslis eleştirinde Kur'an'ın etkisi hakkında bir değerlendirme için bkz., Peter Hughes, “Servetus ve Kur'an”, çev., Talha Fortacı, Oksident, 1/1, (2019), 103116.

${ }^{34}$ Wilbur, Our Unitarian Heritage, 53; Yılmaz, Üniteryanizmim 'in Doğuşu ve Bunu Etkileyen Dinî Faktörler, 56.

${ }^{35}$ Wilbur, Our Unitarian Heritage, I, 59-60.

${ }^{36}$ Yılmaz, Üniteryanizmim 'in Doğuşu ve Bunu Etkileyen Dinî Faktörler, 64.

37 Üniteryanizm tarihinde Servetus'tan sonra ikinci şehit (Willbur, Our Unitarian Heritage, 243) olarak kabul edilen David'in ölümünden sonra tutuklu kaldığ 1 hücrenin duvarında şu ifadelerin yer aldığı bir şiir bulunmuştur: "Sadece birdir üç değil tapındığım Tanrı. Ne aydınlık, ne haç, ne papanın kılıcı, ne ölümün davetkâr yüzü bu gerçeğin ilerlemesini durdurabilsin. Konuşmuş olduğum iman dolu kalp ile hissettiğim şeyi yazdım. Ölümümden sonra gerçek olmayan dogmalar yok olacak. (Ataurrahim, Bir İslâm Peygamberi Hz. İsa, 133.
} 
olduğunu söylemiştir. ${ }^{38}$ Amerika'da Üniteryanizm'in yayılmasında en etkin kişi olarak da William Ellary Channing (1780-1842) ismi zikredilebilir.

XVI. yy'ın ikinci yarısında Polonya ve Transilvanya'da ortaya çıkan ve örgütlü bir kilise kuran Üniteryanizm, kuruluşundan kısa bir süre sonra İngiltere ve Amerika'da taraftar bulmuştur. Bugün de dünyanın çeşitli bölgelerinde faaliyet yürüten Üniteryanlar, Hıristiyanlığın başta teslis olmak üzere pek çok geleneksel doktrinini reddetmekte ve Tanrı'nın birliğini savunmaktadırlar.

Tanrı'nın mutlak anlamda bir olduğunu ve İsa'nın bir beşer olduğunu ısrarla vurgulayan Üniteryanlar, herhangi bir kredoya (amentüye) bağlı değillerdir. Üniteryanlar, inançla ilgili konularda otoritelerin yerine insan aklının belirleyiciliğini esas alırlar. İsa'nın hatırasına saygı göstermekle ve ilminin yüceliğini kabul etmekle birlikte onun yanılmaz olmadığını benimseyen bazı Üniteryanlar, İsa'nın mucizevi doğumunu da kabul etmezler. Onlara göre İsa, Nasıralı marangoz Yusuf ile Meryem'den dünyaya gelen bir insandır. Üniteryanlar, insanın doğuştan günahkâr olduğu yönündeki "asli günah" öğretisini de kabul etmezler. Onlara göre, insanlara Hz. Âdem ve Havva'dan tevarüs eden bir günah yoktur. Herkes kendi eylemlerinden sorumludur ve kimse kimsenin günahını yüklenmez. Hıristiyanlığın aslî günah öğretisine bu şekilde karşı çıkan Üniteryanlar, yüzyıllardır Hıristiyan dünyada uygulanan ve aslî günahtan arınmayı sağlamak için yapılan vaftiz sakrementini “Tanrı'nın bağışlamış olduğu çocuk nimetine karşı şükran duygularının samimi bir ifadesi ve bahşedilen bu çocuğun Tanrı'nın rızasına uygun olarak yetiştirileceği sözünün verilmesi” şeklinde telakki ederek uygulamaktadırlar. Ekmek-şarapla İsa Mesih'in bedenine ve kanına ortak olmak şeklinde anlaşılan Evharistiya sakramenti ise Üniteryanlar tarafından "İsa'nın mesajını hatırlatan, onun hakikat için çektiği acıları canlandıran ve bu suretle insanları dinî-ahlakî olarak geliştirecek bir ayin niteliğine büründürülmüştür. ${ }^{39}$ Kısaca, "Üniteryan mesajı, aklın dinî hayatın gerçeklerine ve deneyimlerine korkusuzca uygulanmasıyla inşa edilen inançtır." ${ }^{*}$

\section{2. Üniteryanlara Göre Teslisin Tutarsızlıkları}

Başlangıcından bugüne Hıristiyan teolojisinin en önemli problemi teslis doktrini olmuş, bununla ilgili tartışmalar birbirinden farklı İsa algılarının ortaya çıkmasına sebep olmuştur. Teslisi savunan ilahiyatçılar, her ne kadar açıkça

\footnotetext{
${ }^{38}$ Yılmaz, Üniteryanizmim'in Doğuşu ve Bunu Etkileyen Dinî Faktörler, 87. $39 \mathrm{https}$ ://www.christianity.com/church/denominations/what-is-unitarianismdiscover-the-history-and-beliefs-of-the-unitarian-church.html (03.11.2021) ${ }^{40}$ Frederick Blount Mott, A Short Unitarian History, London, 1906, 8.
}

Turkish Academic Research Review - Türk Akademik Araştırmalar Dergisi https://dergipark.org.tr/tr/pub/tarr 
zikredilmese de bu öğretinin kaynağının Kitab-1 Mukaddes olduğunu ileri sürmektedirler. Teslisçi ilahiyatçılar bu öğretiyi aşağıdaki Kitab-1 Mukaddes metinlerine dayandırmaktadırlar:

“Başlangıçta söz (kelâm) vardı. Söz Tanrı'yla birlikteydi ve söz Tanrı'ydı. Başlangıçta o, Tanrı'yla birlikteydi. Her şey onun aracılığıyla var oldu, var olan hiçbir şey onsuz olmadi."

"Söz insan (beden) olup aramızda yaşadı. Biz de onun yüceliğini Baba'dan gelen lütuf ve gerçekle dolu olan biricik oğlun yüceliğini gördük." 42

"İmdi siz gidip milletleri şakirt edin. Onları baba, oğul ve kutsal ruh adına vaftiz edin." 43

"Baba! Senin bende olduğun ve benim sende olduğum gibi onlar da biz de olsunlar. Dünya beni senin gönderdiğine iman etsin" ${ }^{\prime 4}$

Yukarıdaki metinlerden hareketle 325 İznik Konsilinde oluşturulan İznik iman bildirgesinde ise şu ifadelere yer verilir:

"Görünen ve görünmeyen şeyleri yaratan, göklerin ve yerin yaratıcısı olan, tek yüce Baba Tanrı'ya inanırım. Ve Tanrı'nın biricik Oğlu, tüm evrenden önce var olan, yaratılmamış, fakat Tanrı'yla aynı öze sahip olan, Kutsal Ruh'un aracılığıyla Bakire Meryem'den doğarak beden alıp, hepimizin kurtuluşunu sağlayan, insan olan ve Pontus Pilatus'un emriyle çarmıha gerilmiş ve acı çekmiş olan ve gömüldükten üç gün sonra dirilmiş olan ve Kutsal Yazılar’a göre göğe alınmış olan ve Baba'nın sağında oturmakta olan ve yaşayanları ve ölüleri yargılamak üzere tekrar görkemle gelecek olan ve egemenliği sonsuza dek sürecek olan Rab İsa Mesih'e inanırım. Ve Rab ve yaşam kaynağı olan, Baba'dan çıkmış olan, Kendisi'ne Babayla ve Oğulla beraber tapınılmakta olan ve Baba ve Oğulla yüceltilen, peygamberler ve elçilerin İnanlılar Topluluğu aracilığıyla açıklamış oldukları Kutsal Ruh'a inanırım. Günahların affı için tek vaftiz olduğunu, ölülerin dirileceğini ve dünyanın sonunun geleceğini beyan ederim.”45

Buna göre tek Allah'ta üç kişilik, şahsiyet ya da teknik bir terim olarak "uknum" bulunduğunu söyleyen; bunlardan birincisini "Baba" ya da "Allah", ikincisini "Kelam"; "İlâhî Kelam” ya da Oğul; üçüncüsünü ise "Kutsal Ruh" olarak isimlendiren Hıristiyan ilahiyatçılar, hal böyle iken Tanrı denilen teslisin aslında "bir" olduğunu iddia etmektedirler. Teslisi oluşturan bu uknumların üçü de tanrılıkta birdir. Baba Tanrı'dan ezelî olarak Oğul Tanrı doğmuş; Baba ve Oğul'dan ezelî olarak Kutsal Ruh zuhur etmiştir. Teslisi oluşturan bu üç Tanrı, cevherlerinin ve doğalarının bir

${ }^{41}$ Yuhanna, 1/1-3.

${ }^{42}$ Yuhanna, 1714.

${ }^{43}$ Matta, 28/19.

${ }^{44}$ Yuhanna, 17/21.

${ }^{45}$ https://www.hristiyanturk.com/forums/topic/znik-man-bildirisi/ 
olmasıyla bir Tanrı'dır, fakat her biri şahıs olarak üç ayrı Tanrı'dır. Tanrı/tanrılık bu üçünün birlikteliğidir. ${ }^{46}$

Hıristiyan ilahiyatçılara göre bu izah ne üç Tanrı ne de üçün bire eşit olduğu anlamına gelir. Teslisin bu izahı tek bir üçgende üç açının bulunması örneğinde olduğu gibi bir tek Tanrı'da üç şahsiyet ya da üç uknum bulunduğunu anlatmaktadır. ${ }^{47}$ Bu naklî delillerle yetinmeyen Hıristiyan ilahiyatçılar, aklî delillerle de bu inancın mantık ilkeleriyle çelişmediğini göstermeye çalışmışlardır. Teslis savunucusu Hıristiyan ilahiyatçılar, "teslis anlayışı ile Tanrı'nın birliğinin nasıl uzlaşabileceği, Tanrı'nın oğul edinmesinin nasıl mümkün görüldüğü’ sorusunu genellikle kral ve güneş örnekleriyle cevaplandırma yoluna gitmişlerdir. ${ }^{48}$ Onlara göre, nasıl ki kelimesi ve ruhu kraldan ayrılamayacağı için, kelimesi ve ruhuyla kral üç değil bir kabul ediliyorsa ve yine nasıl ki ışığı ve 1sısı güneşten ayrı olmamasına rağmen üç güneşten değil bir tek güneşten bahsediliyorsa işte tıpkı bu örneklerde olduğu gibi Tanrı denilen ve Baba, Oğul ve Kutsal Ruh’tan oluşan teslis ile üç varlıktan değil bir tek varlıktan bahsedilmektedir.

Anlaşılan o ki, bütün bu izah ve örnekler başta Servetus olmak üzere Üniteryanları, teslisin Tanrı'nın mutlak anlamda birliğini ifade ettiği konusundaki şüphelerinden arındıracak mahiyette değildir. Onlar teslis doktrininin kaynağının Hıristiyan Kutsal Metinleri olmadığını, aynı şekilde monoteizmi ifade etmekten uzak olan teslis doktrininin akıl ve mantık ilkeleriyle de uyuşmadığını örneklerle açıklayarak teslis karşıtı bir akımın temsilcisi olmuşlardır.

\section{a) Huristiyan Kutsal Metinlerinde Hz. İsa ve Tevhid Vurgusu}

Hıristiyanlığın ilk dönemlerinden itibaren teslis doktrinini tartışma konusu yapan dinî hareketlerle ${ }^{49}$ aynı düzlemde hareket eden Üniteryan hareket, Hıristiyanlığın dejenerasyondan önceki saf halini, Kutsal Kitap'ın da gerçek öğretilerini ortaya çıkarmayı amaç edinmiştir. Bu gayeyle ilk olarak Hıristiyan kutsal metinlerine yönelen Üniteryanlar, teslisin Eski ve Yeni Ahit'ten kaynaklanmadığını,

\footnotetext{
${ }^{46}$ Bayrakdar, Bir Hiristiyan Dogması Teslis, 38-39.

${ }^{47}$ Xavier Jacob, Sorabilir miyiz? Hıristiyanlık Hakkında En Çok Sorulan Sorular, İstanbul, 1999, 15.

${ }^{48}$ krş., Madrigel, Huristiyanların Üçlü-Birlik (Tevhit'de Teslis) İnancı Ne Demek? 3536.

${ }^{49} \mathrm{Bu}$ konuda geniş bilgi ve kapsamlı bir değerlendirme için bkz., Bayrakdar, Bir Hıristiyan Dogması Teslis, 11-34; Ataurrahim, Bir İslâm Peygamberi Hz. İsa, 11-19; Duygu, İsa, Pavlus ve Inciller, $629 \mathrm{vd}$.
}

Turkish Academic Research Review - Türk Akademik Araştırmalar Dergisi https://dergipark.org.tr/tr/pub/tarr 
bu metinlerde Tanrı'nın birliğine vurgu yapıldığını tespit etmişlerdir. Kısacası Hıristiyan kutsal metinlerinde üçlü-birliği kasteden herhangi bir ifadeye rastlamak mümkün değildir. Başka bir ifadeyle teslis, Hıristiyan kutsal metinlerinden kaynaklanan bir öğreti değildir.

Teslise dair herhangi bir tartışmanın insan ile başlaması gerektiğini söyleyerek teslis eleştirisine başlayan Servetus'a göre, Kutsal Kitap Baba'nın tek bir Tanrı, İsa Mesih'in de onun oğlu olduğunu öğretir. Fakat bu, İsa'nın Tanrı olduğu anlamına gelmez. Kilise babalarının sözlerinde ve Hiristiyan kutsal metinlerinde İsa Mesih Tanrı'yı oluşturan bir uknum (Hypostasis) ${ }^{50}$ olarak anılmaz, tam tersine onun insan oluşuna vurgu yapılır. Diğer taraftan Hıristiyan kutsal metinlerinde "Mesih" kelimesinin insan için kullanılıyor olması da İsa'nın insan olduğunu kanıtlamaktadır. Yine İsa'nın mucizeleri onun insan oluşunun kanıtı olarak sunulur. Ona göre, İsa'nın yaşadığı dönemde Eski Ahit ve Helenistik kültürde de kullanılan "Tanrı'nın Oğlu” ifadesi taç giyme törenlerinde krallar için kullanılan bir sıfat idi. Yahudilerin Tanrı ile çok yakın ilişki içinde gördükleri manevi önderleri için kullandıkları bu sıfat daha sonra Hıristiyanlar tarafindan mecaz anlamından soyutlanarak literal anlamıyla değerlendirilmiş ve biyolojik baba-oğul ilişkisi şeklinde anlaşılmıştır. ${ }^{51}$ Kaldı ki, İsa'nın Davud'un soyundan geldiği Hıristiyan kutsal metinlerinde açıkça belirtilmektedir. ${ }^{52}$

Üniteryanizm'in önemli temsilcilerinden biri olan Fausto Paola Sozini (15391604) İsa’nın gerçekte ölümlü bir insan olduğunu vurgulamış; Tanrı olmayan fakat Tanrı'dan vahiy olan İsa'nın elbette yaşamının kutsallı̆̆ı ile diğer insanlardan farklı olması gerektiğini belirtmiştir. Ona göre İsa her ne kadar yaratıcı değilse de ilâhî

\footnotetext{
${ }^{50}$ Hypostasis, Hıristiyan teolojisinde Baba, Oğul ve Kutsal Rûh'tan oluşan teslis doktrinini ifade etmek için kullanılan bir terimdir. Türkçe'ye "öz" ya da "şahıs" olarak çevrilen ve Arapça karşıllı̆ı "uknum" olan bu terimi Origenes "essentia" ya da "ousia" ile eşanlamlı olarak, bir şeyin altta bulunan katmanını ya da özgünlügüün ifade etmek için kullanmıştır. Bu anlamda hypostasys kelimesi, bir putun taş, bronz veya tahta gibi hammaddesini anlatmak için kullanılmaktadır. Bu durumda putun parçalanması, eritilmesi veya yakılması halinde hypostasis yok edilebilmektedir. Bu anlamıyla kullanıldığında söz konusu terim putun somut haline ya da hammaddesine işaret etmektedir. Bununla birlikte 325 İznik Konsili'nde hypostasis ve ousia terimlerinin eşanlamlı kullanımı reddedilerek iki terim arasında kesin bir farklılığın olduğu ortaya konulmuştur. Buna göre "ousia" hypostasin genel ilahi öz ya da tözünü ifade eden bir kavram haline geldi. Bu ayrımla birlikte Hristiyan teolojisinde Tanrı aynı özü taşıyan üç hypostas/şahıs/uknum olarak kabule edilmiştir. Geniş bilgi için bkz., Birger A. Pearson, "Hypostasis", Encyclopedia of Religion, ed. Lindsay Jones, Macmillan Reference, USA, 2005, VI/4239-4242.

${ }^{51}$ Seveto, On The Errors of The Trinity, 11.

${ }^{52}$ Seveto, On The Errors of The Trinity, 8; Bkz., Resullerin İșleri, 13/23.
} 
vizyona ve ilâhî ilhama sahipti ve eşsiz bir yetkiyle, donatılarla insanlığı aydınlatmak üzere gönderilmişti. ${ }^{53}$

Diğer taraftan, teslisi oluşturan üçüncü ayrı bir varlık olarak sunulan Kutsal Ruh ise, Kitab-1 Mukaddes'te asla yer verilmeyen bir kavramdır. Servetus'a göre, Baba, Oğul ve Kutsal Ruh, ulûhiyette içkin olan uknumlar/şahıslar ya da varlıklar/özler değil Tanrı'nın eylem biçimleridir. ${ }^{54}$ Hıristiyanların büyük çoğunluğunca kabul gören teslis formülasyonundaki üç uknum/üç şahıs anlayışını Hıristiyanların dinlerini anlamalarına engel olan mantıksız bir kelime terkibinden ibaret göre Servetus'a göre aynı zamanda bu formülasyon tektanrıcı Yahudi ve Müslümanların Hıristiyanlığa geçişini de neredeyse imkânsız kılmaktadır. ${ }^{55}$

Üniteryan düşünceye göre, kilise babaları ve Hıristiyan kutsal metinleri tek bir Baba Tanrı'yı ve Onun oğlu İsa Mesih'i öğrettiği halde, Yunan felsefenin anlaşılmaz kavramlarıyla çoktanrılı bir inanç sistemi oluşturuldu. Bu haliyle teslis, Kutsal Kitap'ın onaylamadığı irrasyonel bir doktrindir. ${ }^{56}$ Kaldı ki İsa da kendisinin Tanrı'nın bir unsuru olduğunu asla söylememiştir. Bu husus Kur'an'da da benzer şekilde dile getirilmiş, İsa'nın asla böyle bir şey söylemeyeceği, İsa'nın onlara "Benim de Rabbim, sizin de rabbiniz olan Allah'a kulluk edin" ${ }^{\prime 57}$ dediği hatırlatılmıştır. Bu ve başka pek çok benzer ifadeden hareketle Üniteryanların teslis eleştirisinde Kur'an'ın da etkisinden söz etmek mümkündür. $\mathrm{Bu}$ etkiye işaret etmesi açısından Üniteryanzim'in önemli isimlerinden biri olan Francis David'in şu ifadeleri Fatiha Suresi'ne benzerliği açısından oldukça dikkat çekicidir:

“Allah'ın en kesin emri şudur ki, göklerin ve yerin yaratıcısı olan kâdir-i mutlak Allah'tan başka hiç kimseye niyazda bulunulmamalıdır. Gerçeğin öğreticisi Mesih İlâhî kâdir-i Mutlak'tan gayrısına niyaz edilmeyeceğini öğretmiştir. Gerçek niyaz ruhta ve doğrudan Kâdir-i Mutlak'a ödenen şey olarak belirlenir. Sade ibadetin şekli Mesih'e değil, fakat Kâdir-i Mutlak’a yönelir." 58

Üniteryanların İsa hakkındaki düşüncelerinin, ilâhî/tanrısal olanın bölünmezliği ve insanın özsel değeri olmak üzere iki vazgeçilmez ana ilke üzerinde

\footnotetext{
${ }^{53}$ Ataurrahim, Bir İslâm Peygamberi Hz. İsa, 140.

${ }^{54}$ Seveto, On The Errors of The Trinity, 3.

${ }^{55}$ Görüldüğü gibi, Servetus, mevcut teslis anlayışına eleştiriler yöneltmekle birlikte bu doktrini tamamen reddetmiş de değildir. $\mathrm{O}$, teslisi farklı bir şekilde yorumlayarak, özellikle bizzat kendisinin formüle ettiği bir doktrinin Hıristiyan kutsal metinlerine daha uygun olduğunu ve Tanrı'nın birliğini esas aldığını iddia etmektedir. Hughes, "Servetus ve Kur'an", 103.

${ }^{56}$ Seveto, On The Errors of The Trinity, 3.

${ }^{57}$ Mâide, 5/116-117

${ }^{58}$ Ataurrahim, Bir İslâm Peygamberi Hz. İsa, 132.
}

Turkish Academic Research Review - Türk Akademik Araştırmalar Dergisi 
şekillendiğini söyleyebiliriz. Bu temel ilkelerden İsa'nın Tanrı olmadığı sonucu çıkar. Diğer taraftan, İsa’yı bir beşer olarak kabul etmek onun değerini düşürmez. İsa tıpkı bizler gibi bir anne ve babadan dünyaya gelmiştir. Zira onun hayat hikâyesi diğer insanlar gibi yaşadığına tanıklık etmektedir. ${ }^{59}$

İncillerde Hz. İsa'nın tıpkı kendisinden önceki peygamberler gibi Tanrı'nın bir olduğu inancını tebliğ ettiği açıkça görülmektedir. ${ }^{60}$ Servetus'un açıklamalarından, Tanrı'nın birliği konusunda bütün peygamberler ittifak halindeyken Hz. İsa'nın teslis inancını emretmesinin düşünülemeyeceği kanaatinde olduğu sonucunu çıkarabiliriz. Zira Hıristiyan amentüsünün temelini oluşturan Kutsal Kitaplarında Hz. İsa defalarca Tanrı'nın birliğine vurgu yapmaktadır. ${ }^{61}$ Yine İncillerde Hz. İsa'nın Tanrı'nın kulu ve elçisi olduğu açıkça ifade edilmektedir. ${ }^{62}$

Üniteryanlara göre, Baba, Oğul ve Kutsal Ruh'tan oluşan ilâhî yapının üç ayrı şahsa (uknuma) paylaştırılması ve iki tabiatlı İsa anlayışı Kutsal Kitap'ta bulunmadığı gibi, öz (essence) ve cevher (substance) gibi teslisi izah etmek için kullanılan terimler Grekler tarafindan Kiliseye sokulmuştur. ${ }^{63}$ Onlara göre İsa'nın mesajı Yunan düşüncesinin etkisiyle başkalaştırılmıştır. Son zamanlarda yapılan kutsal kitap araştırmaları da ${ }^{64}$ Üniteryanları haklı çıkaracak tarzda göstermiş̧tir ki, İsa bizzat kendisi "Tanrı veya Kutsal Teslisin ikinci uknumu/şahsı olan Tanrı'nın Oğlu" olduğunu asla söylememiş; 1srarla "insanoğlu" olduğuna vurgu yapmıştır. ${ }^{65}$

İsa'nın hiçbir zaman ilahlık iddiasında bulunmadığını itiraf eden Hıristiyan ilahiyatçılardan biri de John Hick'dir. O da Servetus gibi İsa'nın kendisinden yüzyıllarca sonra tanrı konumuna çıkarıldığını düşünmektedir. ${ }^{66}$ Elbette bu husus, yani İsa'nın bir beşer ve Allah'ın gönderdiği bir peygamberi olduğu, İsa'nın

\footnotetext{
${ }^{59}$ Emerton, Unitarian Thought, 148-149.

${ }^{60}$ Serveto, On The Errors of The Trinity, 11-12.

61 "Dinle ey İsrail! Tanrımız Rab tek rabdır." Markos, 12/29-30; Matta, 22/35-37 Benzer ifadeler için bkz., Luka, 10/25-27; Matta, 19/16-17; Markos, 10/17-19; Luka, 18/18-19; Yuhanna, 20/17; Yuhanna, 17/3-4.

62 Yuhanna, 6/38, 44.

${ }^{63}$ Serveto, On The Errors of The Trinity, 3; Willbur, Our Unitaria Heritage, 61.

${ }^{64}$ Batı'da yapılan Kutsal Kitap araştırmalarıyla ilgili geniş bilgi için bkz., Zafer Duygu, Inciller Güvenilir Metinler midir? Metodolojik ve Karşılaş̧tırmalı Analizler, Düşün Yay., İstanbul, 2020.

${ }^{65}$ Weigall, Hıristiyanlığımızdaki Putperestlik, s. 96; Mahmut Aydın, İsa Tanrı mı İnsan mı?, İz Yay., İstanbul, 2002, s. 117.

${ }^{66}$ John Hick, "Hıristiyanların İsa'yı Algılama Biçimi ve Bunun İslâm'ın Anlayışıyla Karşıllaştırılması", çev., Şaban Ali Düzgün, İslâmiyât, III (2000), S. 4, 77.
} 
öğretilerinin daha sonra müntesipleri tarafından değiştirildiği Kur'an'ın da vurguladığı bir husustur. ${ }^{67}$

\section{b) Teslis Doktrininin Rasyonel Tahlili}

Tevhidci Hıristiyanlara göre, bir cevheri üç ayrı unsura (uknuma) paylaştıran, böylece üçlü bir tanrı anlayışına ulaşarak Tanrı'nın birliği ilkesinden uzaklaşan teslis inancı akıl ve mantık ilkeleriyle de bağdaşmamaktadır. Bu haliyle teslis dogması, yalnızca Müslüman ve Yahudilerin değil, kır hayvanlarının bile saçma ve mantıken tutarsız olarak gördükleri bir inanç sistemidir. ${ }^{68}$ Üniteryanlara göre, geleneksel Hıristiyanlık her ne kadar "Tanrı üçtür” sözünü söylemese de üçlü bir tanrı veya üç görünümlü bir Tanrı tasavvuruna ulaşmış, buna rağmen tektanrıcı olduğunu söyleyerek çelişkiye düşmüştür. Üniteryanlara göre, Baba, Oğul ve Kutsal Ruh’tan oluşan ve bir tabiatta üç varlık öngören üçleme, tevhid adı altında hileyle sokuşturulmuş, akla ve mantığa uygunluğu açısından sorunlu olan bir öğretidir. Ayrıca, bu öğretide yer alan İsa'nın hem insanî hem de ilahî tabiata sahip olduğu şeklindeki kabul rasyonel olarak izahı zor hatta imkânsız bir inançtır. Zira bu inanç bir varlıkta iki ayrı tabiatın aynı anda bulunmasının imkânsızlığı sebebiyle çelişiktir. ${ }^{69}$

Tarihin belirli bir döneminde yaşamış ve tarih sahnesinden çekilmiş bir bireyin, nasıl olup da aynı zamanda hem Tanrısal niteliklere/zâtî sıfatlara, hem de insana ait beşeri özelliklere sahip olabileceği, pek çok Hıristiyan ilahiyatçının da zihnini kurcalayan bir sorudur. ${ }^{70}$ Servetus'a göre, teslisi oluşturan uknumların birbirleriyle olan ilişkisi hakkında yapılan yorumlar çözülmesi zor pek çok soruyu gündeme getirmiş ve kafa karışıklığına sebep olmuştur. Hatta Kutsal Kitap’a yabancı olan bu tür saçmalıklar Hıristiyan teolojisini gülünç hale sokmuştur. ${ }^{71}$

Tarihî bir şahsiyetin, nasıl olup da aynı anda bir taraftan Tanrı'ya ait zâtî sıfatlara, diğer taraftan da insana ait niteliklere sahip olabileceği izahı zor pek çok

\footnotetext{
${ }^{67}$ Kur'an, İsa'nın tıpkı kendisinden önce gönderilen peygamberler gibi, tevhid ilkesini yerleștirme ve kendisinden sonra gönderilecek olan son peygamberi müjde ile görevlendirilmiş olduğu halde, peygamber konumundan çıkarılarak Tanrı'nın bir unsuru haline getirildiğini belirtmektedir. Kur'an'da bu tarihsel gerçeklik şu şekilde ifade edilmektedir: "Allah: Ey Meryem oğlu İsa! Insanlara, "beni ve anamı Allah'tan başka iki tanrı bilin” diye sen mi dedin? Buyurduğu zaman o, "Hâşâ! Seni tenzih ederim; hakkım olmayan şeyi söylemek bana yakışmaz. Hem ben söyleseydim şüphesiz sen onu bilirdin. Sen benim içimdekini de bilirsin; hâlbuki ben senin zâtında olanı bilmem. Gizlilikleri eksiksiz bilen yalnızca sensin." (Maide, 5/116)

${ }^{68}$ Serveto, On The Errors of The Trinity, 5.

${ }^{69}$ Serveto, On The Errors of The Trinity, 5.

${ }^{70}$ Aydın, Isa Tanrı mi Insan mi?,117-118.

${ }^{71}$ Serveto, On The Errors of The Trinity, 5.
}

Turkish Academic Research Review - Türk Akademik Araştırmalar Dergisi 
teolojik probleme kapı aralamaktadır. Armstrong'un da dediği gibi, bu teolojik problemlerin çözümü adına çeşitli formüller geliştirilse de Hıristiyan ilahiyatçıların bu konudaki kafa karışıklığı devam etmektedir. ${ }^{72} \mathrm{Bu}$ anlamda, bir varlıkta iki ayrı tabiatın aynı anda bulunması temeline dayanan teslis öğretisi üniteryanlar tarafından tutarsız bir doktrin olarak görülmektedir. Socianus'a göre, fânîlik ve ebedîlik gibi birbirine zıt iki özün tek bir şahsiyette bir arada bulunması aklen mümkün değildir. Keza bir varlık aynı anda hem ezelî hem de başlangıcı olan bir varlık olamaz. Bunun tabii bir sonucu olarak, bir varlığı hem ilahî olarak sonsuz, hem de insanî olarak sonlu şeklinde düşünemeyiz. Tarihî bir şahsiyetin, aynı anda ilâhî olarak her şeyin yaratıcısı, bununla birlikte insanî olarak yaratma kabiliyetinden yoksun olması imkân dâhilinde değildir. ${ }^{73}$ Başka bir ifadeyle bir varlık ya yaratıcıdır ya da yaratılandır; yaratııı ise yaratılan olamaz, yaratılmış ise yaratıcı olamaz. Kısacası bir varlıkta iki ayrı tabiat mantık ilkeleriyle çelişmektedir.

Teslis karşıtı görüşleriyle bilinen John Biddle'nin, Kutsal Ruh'un İlahlığını Reddeden On iki İddiası, "birden fazla Tanrı'nın varlığı akıl ilkeleriyle bağdaşmaz" önermesine dayanan temânu delilini çağrıştırmaktadır. Biddle'nin "On iki iddia”sının özeti şu şekildedir:

I. Tanrı'dan farklı olan Tanrı değildir.

Kutsal Ruh Tanrı'dan farklıdır.

O halde Kutsal Ruh Tanrı değildir.

II. İsrailoğullarına Kutsal Ruh’u gönderen Yehova’dır.

Öyleyse Kutsal Ruh Yehova yahut Tanrı değildir.

III. Kendi iradesiyle konuşmayan Tanrı değildir.

Kutsal Ruh kendi iradesiyle konuşamaz.

O halde Kutsal Ruh Tanrı değildir.

${ }^{72}$ Karen Armstong, Tanrı'nın Tarihi, çev., Oktay Özel-hamide Koyukan-Kudret Emiroğlu, Ayraç Yay., Ankara, 1998, 158.

${ }^{73}$ Ataurrahim, Bir İslâm Peygamberi Hz. İsa, 141. 
IV. Tanrı'ya hiçbir şey öğretilemez.

Mesih öğretilen şeyleri söyler.

O halde Mesih Tanrı değildir.

V. İsa şöyle der: Herkese her şeyi veren yalnız Tanrı'dır.

Başkalarından alan Tanrı değildir.

Öyleyse Mesih Tanrı ddeğildir.

VI. Başka biri tarafından gönderilen Tanrı değildir.

Kutsal Ruh Tanrı tarafından gönderilmiştir.

O halde Kutsal Ruh Tanrı değildir.

VII. Her şeyi veremeyen Tanrı değildir.

Tanrı'nın verdiğini alan her şeyin vericisi değildir.

Tanrı'nın verdiği her şeyin alıcısı insandır.

Verilen, vericinin kudret ve tertibindedir.

O halde başkasının tertibinde ve kudretinde görülen Tanrı imajı saçmadır.

VIII. Yeri değişen Tanrı değildir.

Kutsal Ruh yer değiştirir.

O halde Kutsal Ruh Tanrı değildir.

IX. Hükmün gelmesi için Mesih'e ibadet eden Tanrı değildir.

Kutsal Ruh böyle yapmıştır.

O halde Kutsal Ruh Tanrı değildir.

X. Kendisine iman edilmeyen Tanrı değildir.

İnsanlar Kutsal Ruha’a iman etmediler

Öyleyse Kutsal Ruh Tanrı değildir. 
XI. Tanrı'da olduğu için ikinci elden işiten Mesih, Tanrı'dan vahyedilen şeyleri bildirir.

Kutsal Ruh da Tanrı'dan aldıklarını vaz etmiştir.

O halde Kutsal Ruh Tanrı değildir.

XII. Tanrı'dan pek çok hususta farklı olan Tanrı değildir.

Kutsal Ruh Tanrı'dan pek çok hususta farklıdır.

O halde Kutsal Ruh Tanrı değildir.

$\mathrm{Bu}$ iddiaların yer aldığı broşürün nüshaları 1645 yılında toplatıldı ve Biddle hapse atıldı. Parlemento önünde özür dilemeye davet edildiyse de bunu kabul etmedi ve Kutsal Ruh'un ilahlığını tekrar reddetti. 1647 'de tekrar basılan broşür, parlementonun emriyle toplatıldı ve yakıldı. Bu on iki iddiası ile teslis doktrinini, İsa'nın ilahlığını, Kutsal Ruh'un ilahlığını reddeden Biddle kilise tarafından ölüme mahkûm edildi ve 2 Mayıs 1648 'te idam edildi. ${ }^{74}$

\section{Sonuç}

Tevhidci Hıristiyanlar, Hz. İsa’nın gerçek öğretisinin tektanrıcılığı esas aldığını, daha sonraki dönemlerde bu öğretinin çeşitli tesirlerle aslından uzaklaşarak bozulduğunu iddia etmektedirler. Âlemdeki düzen ve intizamın Tanrı'nın birliğine bağl1 olduğunu söyleyerek tevhide vurgu yapan Üniteryanlar, İsa Mesih'in ilahlaştırılmasına karşı çıkarlar. Eski Ahit'te de Yeni Ahit’te de Tanrı'nın mutlak anlamda bir olduğunun vurgulandığını dile getiren Üniteryanlara göre, teslis öğretisinin kaynağı Hıristiyan kutsal metinleri değildir. Onlara göre, insanların kendilerini, içindeki yaşadıkları evreni ve Tanrılarını anlama konusunda uzun bir mücadelenin kaydı olarak gördükleri İncil, insan yazarlar tarafından kaleme alınmış en iyi rehberdir. Ancak İncil, tartışılmaz bir otorite değildir. Bu yüzden içeriği akıl ve vicdan ışığında yorumlanmalıdır. Zira İsa'nın kendisi de Kutsal Kitap'ın yanılmazlığından bahsetmemiştir.

Genelde tevhidci Hıristiyanların özelde de Üniteryanların Hıristiyanlık tarihi boyunca maskelenen ve değişime uğratılan İsa'nın üzerindeki maskeyi kaldırmayı ve Hıristiyanlığın orijinal ve saf haline ulaşmayı hedefledikleri söylenebilir. Üniteryanların teslis eleştirilerinde dikkat çeken temel husus, kutsal metinlerin teslis dogmasına kaynaklık etmediği yönündeki tespitleridir. Onlar bu iddialarını

\footnotetext{
${ }^{74}$ Ataurrahim, Bir İslâm Peygamberi Hz. İsa, 145.
} 
ispatlamak için Tanrı'nın birliğini ve İsa'nın bir kul ve elçi olduğunu belirten pek çok İncil pasajını örnek gösterirler. İkinci olarak onların teslis eleştirilerinde rasyonel tahliller göze çarpmaktadır. Onlara göre, teslis öğretisi akıl ve mantık ilkeleriyle bağdaşmayan, sonradan çeşitli etkilerle oluşturulmuş bir inanç sistemidir.

\section{Kaynakça}

Allen, Joseph Hanry. Historical Sketch of the Unitarian Moviment Since the Reformation. New York: The American Church History Series, X, The Chiristian Literature Co., 1894.

Ataurrahîm, Muhammed. Bir İslâm Peygamberi Hz. İsa. çev., Kürşat Demirci. İstanbul: İnsan Yay., 1997.

Armstong, Karen. Tanrı'nın Tarihi. çev., Oktay Özel-hamide Koyukan-Kudret Emiroğlu. Ayraç Yay., Ankara, 1998, 158.

Auer, J. A. C. Fagginger. "Unitarianism", The Encyclopedia Americana, XXVII, New York-Chiciago-Washington: 1957

Aydın, Mahmut. İsa Tanrı mı İnsan mı?. İz Yay., İstanbul, 2002.

Bayrakdar, Mehmet. Bir Hıristiyan Dogması Teslis. Ankara: Ankara Okulu Yay., 2007.

Behiy, Muhammed. İslâm Düşüncesinin Illâhî Yönü. çev., Sabri Hizmetli. Ankara: Fecr Yay., 1992.

Cevizci, Ahmet. Felsefe Sözlü̆g̈ü. İstanbul: Paradigma Yay., 2002.

Chadwick, John White. Old and New Unitarian Belief. Boston: 1894.

Çelik, Mehmet. Süryani Tarihi. Ankara: Ayraç Yay., 1996.

Duygu, Zafer. İsa, Pavlus ve İnciller. İstanbul: Düşün Yay., 2021.

Duygu, Zafer. Inciller Güvenilir Metinler midir? Metodolojik ve Karşılaştırmalı Analizler. İstanbul: Düşün Yay., 2020.

Ebu Zehra, Muhammed. Hiristiyanlık Üzerine Konferanslar. çev., Akif Nuri. İstanbul: Fikir Yay, 1978.

Emerton, Ephraim. Unitarian Thought. New Yrok: The Macmillan Company, 1916.

Fox, Arthur W. Michael Servetus. London: The Unitarian Library, ty.

Frederick Blount Mott, A Short Unitarian History, London, 1906.

Godbey, J. C. "Unitarian Universalist Assocation". The Encyklopedia of Religion. ed. Mircea Eliade, New York: Macmillan Publishing Company, 1987, C. XV, s. 143-146.

Güngör, Ali İsra. Vatikan, Misyon ve Diyalog. Ankara: Alperen Yay., 2002.

Turkish Academic Research Review - Türk Akademik Araştırmalar Dergisi https://dergipark.org.tr/tr/pub/tarr 
Hall, Alfred. The Beleifs of A Unitarian. London: 1947.

Hick, John. "Hıristiyanların İsa'yı Algılama Biçimi ve Bunun İslâm’ın Anlayışıyla Karşılaştırılması". çev., Şaban Ali Düzgün. İslâmiyât, III (2000), S. 4,

Hughes, Peter. "Servetus ve Kur'an”. çev., Talha Fortac1. Oksident, 1/1, (2019).

https://www.christianity.com/church/denominations/what-is-unitarianismdiscover-the-history-and-beliefs-of-the-unitarian-church.html

Jacob, Xavier. Sorabilir miyiz? Hıristiyanlık Hakkında En Çok Sorulan Sorular. İstanbul: Ohan Matbbacılık, 1999.

Lacguna, Catherine M. “Trinity”. The Encyclopedia of Religion. ed. Mircea Eliade. New York: Macmillan Publishing Company, 1987. XV, s. 53-57.

Layman, C. Stephen. "Tritheism and the Trinity". Faith and Pholosophy, vol. 5, No. 3, July 1988, 291- 298.

Macnamara, John - Reyes, Marie La Palme - Reyes, Gonzalo E. "Logic and the Trinity". Faith and Pholosophy. vol. 11, no. 1, January 1994, s. 3-18.

Madrigel, Carlos. Hıristiyanların Üçlü-Birlik (Tevhit'de Teslis) Inancı Ne Demek? İstanbul: Müjde Yayıncılık, 1995

Michel, Thomas. Hıristiyan Tanrıbilimine Giriş. İstanbul: Ohan Yay., 1992.

Pearson, Birger A. "Hypostasis". Encyclopedia of Religion. ed. Lindsay Jones. Macmillan Reference, USA: 2005, VI/4239-4242.

Rahner, Karl. "Trinity, Divine”. Encyclopedia of Theology. ed., Karl Rahner, New York: Crossroad, 1986. ss. 1755-1771.

Serveto, Michael. On The Errors of The Trinity, Libri Septem. Tr., by Earl Morse Willbur. Cambridge: Harward Theological Studies, XVI, Harwarad University Press, 1932.

Swinburne, Richard. "Trinity; A Defense of the Doctrine of the Trinity". Philosophy of Religion. ed., Lane Crcig, New Jersey: Rutgers University Pres. 2002, ss. 556-567.

Tarrant, William George. Unitarianism. London: 1912.

Tekin, Kübra. Erken Orta Çă̆'daki Arianizm Tartışmaları ve Günümüz Üniteryanizm'e Etkileri. (Tokat Gazi Osman Paşa Üniversitesi Sosyal Bilimler Enstitüsü, Yayımlanmamış Yüksek Lisans Tezi), Tokat: 2019.

Trol, Christian W. Müslümanlar Soruyor Hıristiyanlar Yanıtlıyor. çev., Robert Kaya. İstanbul: t.y.

Unitarianism: Its Origin and History. Americam Unitarian Assocation. Boston: 1889. 
Weigall, Arthur. Hiristiyanlı̆̆ımızdaki Putperestlik. İstanbul: Ozan Yay., 2002.

Willbur, Earl Morse. A History of Unitarianism -In Transylvania, England and America. Cambridge: Harwarad University Press, 1952.

Willbur, Earl Morse. A History of Unitarianism-Socinianism and its Antecedents. Cambridge: Harwarad University Press, 1945.

Willbur, Earl Morse. Our Unitarian Heritage. Boston: Beacon Press, 1925.

Yılmaz, İsmail. Üniteryanizmim 'in Doğuşu ve Bunu Etkileyen Dinî Faktörler. Uludağ Üniversitesi Sosyal Bilimler Enstitüsü Yayımlanmamış Doktora Tezi. Bursa: 1994.

Turkish Academic Research Review - Türk Akademik Araştırmalar Dergisi https://dergipark.org.tr/tr/pub/tarr 